\title{
Implementasi Algoritma Djikstra Untuk Menentukan Lokasi dan Jarak Tempuh Terpendek Kampus IT di Jakarta
}

\author{
Jeki Sauwani $\mathbf{S}^{1}$, Vitcky Nanda Putra $\mathbf{S}^{2}$, Halim Agung $\mathbf{S}^{3}$ \\ ${ }^{1}$ Universitas Bunda Mulia \\ e-mail: mr.jekisauwani@gmail.com \\ ${ }^{2}$ Universitas Bunda Mulia \\ e-mail: vitkynptr@gmail.com \\ ${ }^{3}$ Universitas Bunda Mulia \\ e-mail: hagung@bundamulia.ac.id
}

\begin{abstract}
Abstrak
Kemajuan teknologi saat ini tentunya sangat memudahkan masyarakat untuk mencari informasi terkait perguruan tinggi yang diminati, baik itu fasilitas, alamat, dan jalan menuju lokasi, namun pada kenyataannya masih banyak dari masyarakat baik berasal dari dalam maupun luar kota Jakarta yang belum mengetahui lokasi dan rute jalan yang harus dilewati untuk menuju ke perguruan tinggi dengan program studi Teknik Informatika di Jakarta. Hal ini dikarenakan kurang jelasnya informasi yang di dapat. Proses pencarian rute akan menggunakan algoritma djikstra dan hasil akhir yang ditampilkan adalah informasi rute jalan yang harus dilalui, juga peta yang menampilkan lokasi perguruan tinggi dengan program studi Teknik Informatika di Jakarta. Hasil pengujian dapat disimpulkan bahwa tingkat ketepatan rute yang didapatkan dari aplikasi ini adalah sebesar $75 \%$, dikarenakan masih ada beberapa posisi dan rute yang tidak $100 \%$ akurat.
\end{abstract}

Kata Kunci : Kampus IT, Penentuan jalur terpendek, Algoritma Djikstra

\section{Abstract}

Today's technological improvement certainly make it easier for people to find information regarding universities, both addresses, and roads to locations, but in reality there are still many from both inside and outside Jakarta who dont know the location and route to go to college with an Informatics Engineering study program in Jakarta. This is due to the lack of clarity in the information obtained. The route search process will use the djikstra algorithm and the final results displayed are information on the route that must be passed, as well as a map that displays the location of universities with an Informatics Engineering study program in Jakarta. The test results can be concluded that the level of accuracy of the routes obtained from this application is $75 \%$, because there are still several positions and routes that are not $100 \%$ accurate.

Keywords: IT Campus, Determination of the shortest path, Dijkstra algorithm

\section{Pendahuluan}

DKI Jakarta adalah kota dengan jumlah perguruan tinggi terbanyak di Indonesia, dimana masing-masing perguruan tingginya memiliki berbagai macam program studi, salah satunya adalah program studi Teknik Informatika.

Program studi Teknik Informatika merupakan salah satu program studi yang memiliki peningkatan perkembangan yang sangat pesat saat ini. Kemajuan teknologi di era globalisasi merupakan salah satu faktor yang mempengaruhi perkembangan program studi ini. Hal ini meningkatkan keingintahuan dan minat masyarakat terhadap program studi ini dan menjadikannya sebagai salah satu tujuan untuk melanjutkan pendidikan ke perguruan tinggi. 
Tingginya animo masyarakat terhadap program studi Teknik Informatika tentunya tidak hanya berasal dari warga kota Jakarta saja melainkan juga dari berbagai daerah di Indonesia. Banyaknya perguruan tinggi dengan kualitas yang sangat baik di Jakarta menjadi daya tarik tersendiri bagi masyarakat luas untuk melanjutkan pendidikannya ke perguruan tinggi yang ada di Jakarta.

Kemajuan teknologi saat ini tentunya sangat memudahkan masyarakat untuk mencari informasi terkait perguruan tinggi yang diminati, baik itu fasilitas, alamat, dan jalan menuju lokasi, namun pada kenyataannya masih banyak dari masyarakat baik berasal dari dalam maupun luar kota Jakarta yang belum mengetahui lokasi dan rute jalan yang harus dilewati untuk menuju ke perguruan tinggi dengan program studi Teknik Informatika di Jakarta. Hal ini dikarenakan kurang detailnya informasi yang di dapat.

Dengan keunggulan jaringan internet dan sistem informasi geografis di dalamnya, akan dikembangkan sebuah sistem untuk mengatasi persoalan pencarian lokasi dan pencarian rute terpendek menuju lokasi perguruan tinggi yang ditentukan.

Proses pencarian rute akan menggunakan algoritma djikstra dan hasil akhir yang ditampilkan adalah informasi rute jalan yang harus dilalui, juga peta yang menampilkan lokasi perguruan tinggi dengan program studi Teknik Informatika di Jakarta.

\section{Metode Penelitian}

\section{Metode Pengumpulan Data}

Dalam penelitian ini menggunakan bebrapa metodologi untuk mengumpulkan data yaitu sebagai berikut:

1. Studi pustaka, mengumpulkan data dari membaca beberapa buku, jurnal, dan karya ilmiah yang berhubungan dengan penggunaan algoritma djikstra dan penentuan jarak terpendek dalam berbagai kasus.

2. Dokumentasi, dalam metode ini peneliti mencari data mengenai hal-hal berupa catatan, transkrip, buku, surat kabar, majalah, agenda dan sebagainya.

3. Observasi

Peneliti melakukan observasi langsung keadaan rute jalan kebeberapa perguruan tinggi dengan program studi
Teknik Informatika di Jakarta guna mendapatkan data dan informasi yang akurat terkait lokasi dan rute yang dilewati menuju masing masing perguruan tinggi.

\section{Metode Pengembangan Sistem}

Metode pengembangan sistem yang digunakan dalam peneliatian ini adalah metode waterfall dengan urutan proses sebagai berikut:

1. Requirements Analysis and Definition

Pada tahap ini dikumpulkan secara lengkap kebutuhan-kebutuhan mengenai perangkat lunak, kemudian peneliti menganalisis apa saja kebutuhan-kebutuhan yang dibutuhkan pada perangkat lunak.

2. System and Software Design

Pada tahap ini peneliti melakukan desain setelah kebutuhan selesai dikumpulkan secara lengkap.

3. Implementation and Unit Testing Pada proses ini desain program diterjemahkan kedalam kode-kode dengan menggunakan bahasa pemrograman yang sudah ditentukan. Program yang dibangun langsung diuji dengan tujuan agar program dapat diuji dengan baik.

4. Intergration and System Testing

Pada proses ini adalah penyatuan unitunit program. Setelah itu dilakukan pengujian secara keseluruhan mengenai perangkat lunak pencarian pergurua tinggi dengan prodi TI di Jakarta.

5. Operation and Maintenance
Pada proses ini dilakukan pengujicobaan perangkat lunak pencarian restoran, tujuan dari proses ini adalah mengurangi kesalahan yang ada pada perangkat lunak yang dibuat dan sesuai dengan kebutuhan. mengoperasikan program dilingkungannya dan melakukan pemeliharaan, seperti penyesuaian.

\section{Hasil dan Pembahasan}

Pencarian jarak terpendek pada penelitian ini menggunakan algoritma djikstra, penentuan jarak terpendek dimulai dengan menghitung jarak user ke masingmasing kampus IT di Jakarta. Perhitungan jarak dilakukan oleh sistem, dengan menentukan posisi awal user pada peta dan memilih tujuan kampus IT di Jakarta yang ingin dikunjungi. Perhitungan jarak ini akan menghasilkan rekomendasi rute 
perjalanan yang akan dilewati user menuju ke kampus IT tujuan. Dalam mencari solusi, algoritma djikstra menggunakan prinsip greedy, yaitu mencari solusi optimum pada setiap langkah yang dilalui, dengan tujuan untuk mendapatkan solusi optimum pada langkah selanjutnya yang akan mengarah pada solusi terbaik. Hal ini membuat kompleksitas waktu algoritma djikstra menjadi cukup besar, yaitu seperti pada rumus persamaan berikut :

$$
\mathrm{O}\left(\mathrm{V}^{*} \log (\mathrm{v}+\mathrm{e})\right)
$$

Rumus 1. Persamaan algoritma djikstra [1]

Dimana $v$ dan e adalah simpul dan sisi pada graf yang digunakan.

Input dari algoritma djikstra berupa sebuah graf berbobot $\mathrm{G}(\mathrm{e}, \mathrm{v})$, sedangkan outputnya berapa rute terpendek dari simpul awal (start) ke masing-masing simpul yang ada pada graf. Dengan demikian algoritma djikstra dapat menemukan solusi terbaik.

Cara kerja algoritma djikstra hampir sama dengan cara kerja algoritma BFS yaitu dengan menggunakan prinsip antrian (queue), akan tetapi antrian yang digunakan algoritma djikstra adalah antrian berprioritas (priority queue). Jadi hanya simpul yang memiliki prioritas tertinggi yang akan ditelusuri. Dalam menentukan simpul yang berprioritas, algoritma ini membandingkan setiap nilai (bobot) dari simpul yang berada pada satu level. Selanjutnya nilai (bobot) dari setiap simpul tersebut disimpan untuk dibandingkan dengan nilai yang akan ditemukan dari rute yang baru ditemukan kemudian, begitu seterusnya sampai ditemukan simpul yang di cari.

Berikut ini langkah-langkah algoritma djikstra dalam mencari rute terpendek pada sebuah graf:

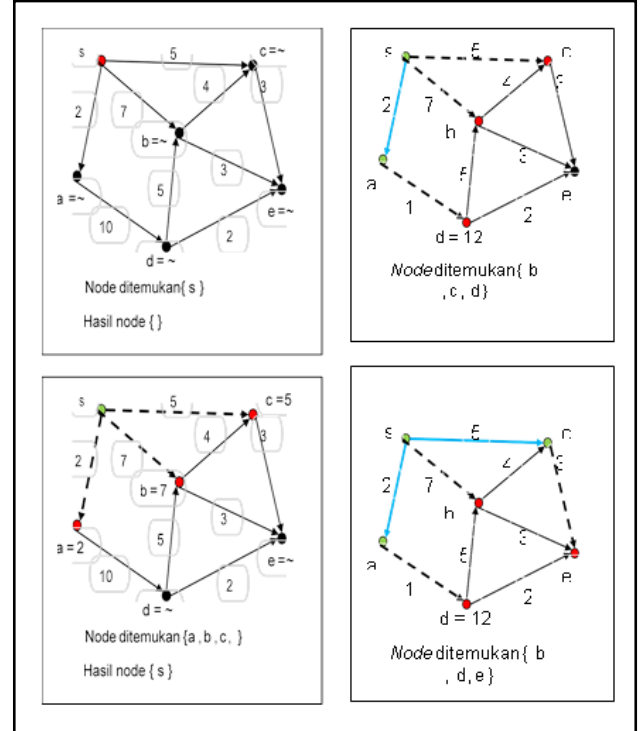

Gambar 1. Proses pencarian rute algoritma djikstra pada Graf.[2]

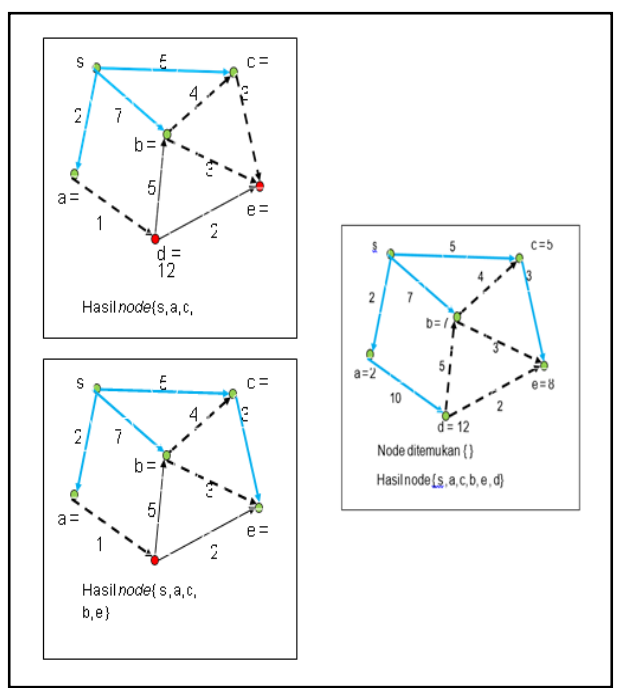

Gambar 2. Proses lanjutan pencarian rute algoritma Djikstra pada Graf.[3]

Setelah langkah-langkah tersebut dijalankan akan dihasilkan solusi terbaik berupa rute perjalanan terpendek menuju lokasi tujuan.

Algoritma ini juga digunakan dalam penelitian yang berjudul Penentuan Rute Terpendek Pendistribusian Naskah Ujian Nasional Menggunakan Algoritma Dijkstra [7]. Hasil dari penelitian tersebut adalah algoritma dijkstra mampu menyelesaikan permasalahan pendistribusian naskah ujian nasional di kota Binjai dengan efektif dan cepat, hasil penelitian ini dapat dijadikan acuan untuk pengembangan lanjutan. Selain dari itu juga ada penelitian lain yaitu menggunakan Protokol Routing OSPF (Open Source Path First) Menggunakan 
GNS3 Untuk Mencari Jalur Terpendek Dengan Menerapkan Algoritma Dijkstra [8]. Dan kesimpulannya adalah hasil penelitian ini menunjukaan bahwa algorima Dijkstra dapat memberikan solusi routing dengan bobot terkecil ke semua titik yang dituju, selain algoritma Dijkstra mampu memaksimalkan kerja protocol OSPF untuk dapat mengubah topologi apabila terdapat kegagalan link, dan perubahan dapat dilakukan dalam hitungan detik. Penelitian lainnya berjudul dijkstra-based Terrain Generation Using Advanced Weight Functions [9]. Kesimpulan dari penelitian ini adalah algoritma dijkstra dapat dimanfaatkan untuk pemetaan visualisasi bentang alam yang juga merupakan bagian dari sistem informasi geografis. Dalam hal ini algoritma dijsktra mampu memberikan informasi terkait ketinggian suatu dataran dengan memanfaatkan node-node yang terbentuk dari algoritma. Dalam penelitian Path Optimization Study for Vehicles Evacuation Based on Dijkstra algorithm [10]. Dengan hasil penelitian algoritma dijkstra diguanakan untuk menentukan jalur terpendek untuk melakukan percepatan eveakuasi dalam keadaan darurat. Dalam penentuan jalur terpendek memperhitungkan kepadatan lalu lintas oleh kendaraan sabagai salah faktor yang kemungkinan dapat menghambat evakuasi. Dari penelitian ini disimpulkan bahwa kepadatan lalu lintas mampu mempengaruhi efisiensi evakuasi. Dalam penelitian Railway Route Optimization System Using Dijkstra Method [11]. Disimpulkan dengan memanfaatkan algoritma Dijkstra, rute perjalanan kereta api mampu dipetakan sehingga dapat diketahui keberangkatan kereta di stasiun awal dan kemana stasiun tujuannya. Hal ini mampu memecahkan masalah optimalisasi , dimana masyarakat dimudahkan untuk mengetahui stasiun kereta mana saja ,kereta api yang menuju tujuan mereka tersedia. Dalam penelitian Geografic Dijkstra-Based Multicast Algorithm For Wireless Sensor Networks [12], disimpulkan bahwa algoritma dijskstra bereperan dalam penentuan routing akses dalam jaringan komunikasi multicast. Dengan memanfaatkan node-node yang terbentuk mampu mengurangi beban resource yang diperlukan oleh NSW. Hasil penelitian ini menunjukan bahwa algoritma dijkstra mampu memberikan routing yang efektif dan efisien. Dalam penelitian
Implementasi Algoritma Dijkstra Dalam Aplikasi Untuk Menentukan Lintasan Terpendek Jalan Darat Antar Kota Di Sumatera Bagian Selatan [13], kesimpulannya adalah menjelaskan bagaimana algoritma dijkstra dimanfaatkan dalam penentuan rute terpendek akses dari satu kota ke kota lainnya melalui jalur darat di provinsi Sumatera Selatan. Hasil dari penelitian ini menunjukan bahwa algoritma dijkstra mampu memberikan rute terpendek yang optimal dengan bobot terkecil. Dalam penelitian Implementasi Algoritma Dijkstra Dalam Menemukan Jarak Terdekat Dari Lokasi Pengguna Ke Tanaman Yang Di Tuju Berbasis Android (Studi Kasus di Kebun Raya Purwodadi) [14], ditarik kesimpulan Pada penelitian ini algoritma Dijkstra mampu memberikan solusi untuk melakukan pencarian lokasi tanaman yang ingin dituju dengan memeberikan jalur atau rute jalan yang efeketif dengan presentase kepuasan responden mencapai $70 \%$. Dalam penelitian Anapplication of Dijkstra's Algorithm to shortest route problem [16], dengan hasil Algoritma Dijkstra digunakan untuk memaksimalkan pendistribusian produk dari suatu perusahaan untuk dikirimkan ke setiap langganannya, dalam penelitian ini menunjukan algoritma Dijkstra mampu memberikan jalur distribusi yang efektif, sehingga perushaan menghemat waktu distribusi serta cost yang dikeluarkan. Dan terahir dalam penelitian Pencarian Spbu Terdekat Dan Penentuan Jarak Terpendek Menggunakan Algoritma Dijkstra (Studi Kasus Di Kabupaten Jember) [17], ditarik kesimpulan penelitian ini menerapkan algoritma dijsktra untuk pencarian lokasi spbu terdekat dari tempat user selain itu, perhitungan dibagi menjadi dua yang diambil berdasarkan jenis kendaraan motor dan mobil. Algoritma Dijkstra mampu memberikan rute terbaik untuk menuju SPBU sesua dengan jenis kendaraan yang digunakan.

\subsection{Penjelasan sistem berjalan}

$$
\text { Sistem berjalan dengan }
$$

menggunakan platform berbasis website, dimana user perlu terhubung dengan jaringan internet untuk mengakses sistem ini. Proses berjalannya sistem digambarkan melalui sebuah flowchart sebagai berikut : 


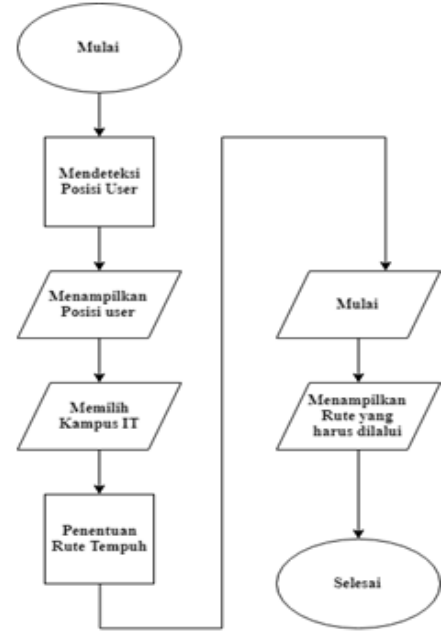

Gambar 3. Flowchart

Dari flowchart diatas dapat dijabarkan prosesnya sebagai berikut:

Sistem mendeteksi posisi terakhir user saat menggunakan aplikasi ini, lalu Posisi ditampilkan diatas sebuah map. User memilih kampus tujuan pada menu yang telah disediakan. Setelah lokasi tujuan ditentukan sistem akan membuat rute terpendek menuju lokasi melalui perhitungan algorima djikstra. Hasil perhitungan akan berupa rute ditampilkan pada map untuk dapat digunakan user.

\subsection{Implementasi sistem}

\section{Form Home}

Merupakan tampilan utama pada saat user membuka website pencarian jalur terpendek menuju kampus IT di Jakarta.

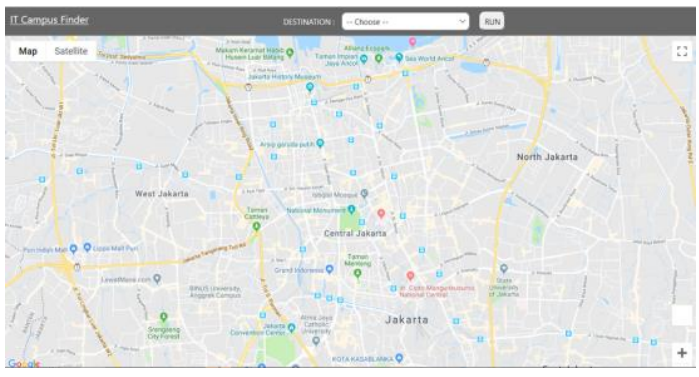

\section{Gambar 4. Form home} dengan map standar

Pada home user dapat menentukan lokasi awal dan lokasi kampus mana yang ingin di kunjungi dengan memilih pada menu pilih yang tersedia pada map. Lalu menekan run untuk mendapatkan rute menuju lokasi kampus tujuan.

\section{Form Pilih Kampus IT}

Tampilan data kampus IT yang ada di Jakarta dapat diakses pada menu pilih dengan melakukan klik satu kali pada menu tersebut, maka akan ditampilkan data kampus IT di Jakarta.

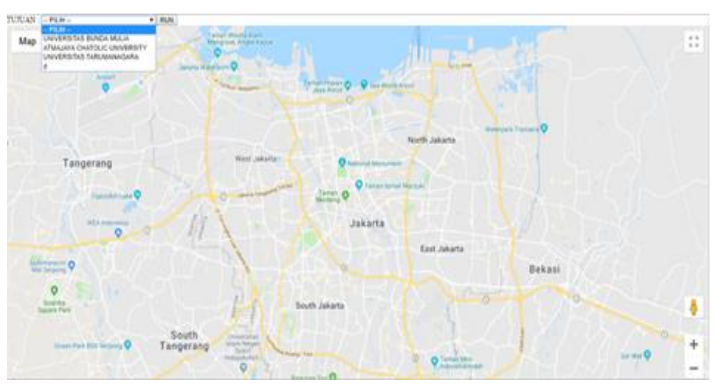

Gambar 5. Tampilan pilih kampus IT tujuan.

\section{Form Tampilan Jalur Pilihan}

Tampilan rute yang harus dilalui oleh user

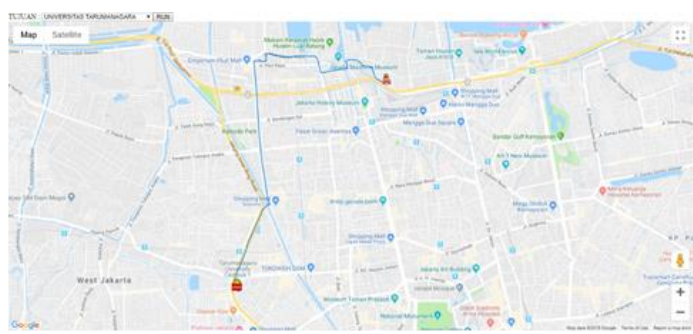

Gambar 6. Tampilan rute yang dilalui dengan map standar

Rute jalan yang akan didapatkan user ditandai dengan jalur berwarna biru pada map. Selain itu akan ditampilkan dua marker lainnya sebagai penanda lokasi user dan lokasi tujuan.

\subsection{Hasil pengujian}

Hasil Pengujian yang dilakukan untuk membuktikan bahwa algoritma djikstra mampu memberikan solusi optimum jalur terpendek dalam penelitian ini, berikut penjabaran hasil pengujian.

1. Bank Sinar Mas Petojo menuju Univeritas Bunda Mulia 


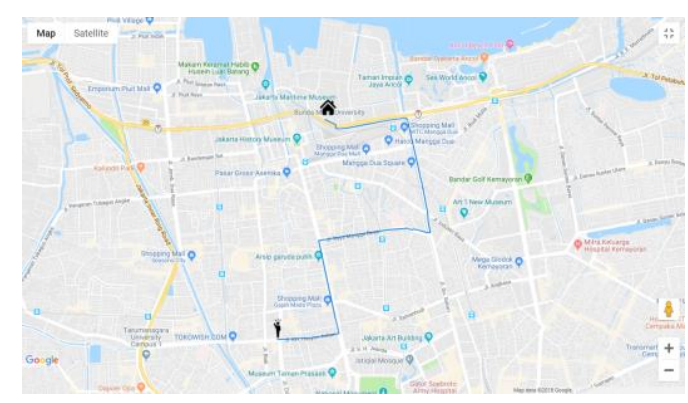

Gambar 7. Rute dari Bank Sinar Mas menuju Universitas Bunda Mulia

Menunjukan rute terpendek yang dapat dilalui dari Bank Sinar Mas Petojo menuju Univeritas Bunda Mulia.

2. Zul Ladies Fashion Jl. Kp. Rw. Sawah menuju Universitas Katolik Atmajaya

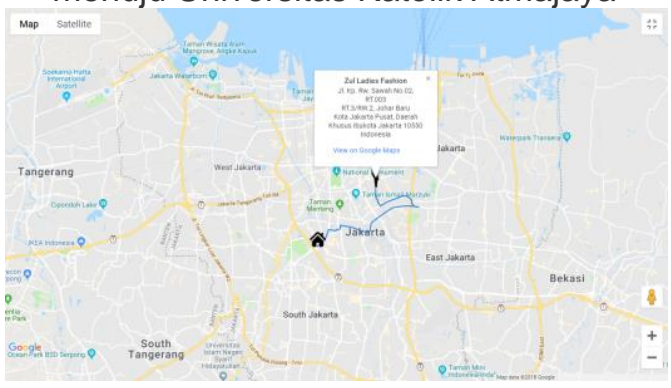

Gambar 8. Rute dari Zul Ladies Fashion menuju Universitas Katolik Atmajaya

Menunjukan rute terpendek yang dapat dilalui dari Zul Ladies Fashion Jl. Kp. Rw. Sawah menuju Univeritas Katolik Atmajaya.

3. Maharani Collection, Jatinegara menuju Universitas Negeri Jakarta

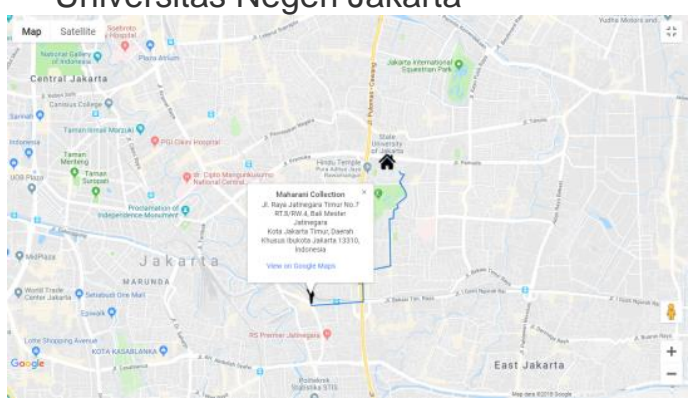

Gambar 9. Rute dari Maharani Collection menuju Universitas Negeri Jakarta

Menunjukan rute terpendek yang dapat dilalui dari Maharani Collection, Jatinegara menuju Univeritas Negeri Jakarta.
4. Bakso Sengon Kramat Jaya-Alidin Toyo menuju UNTAR

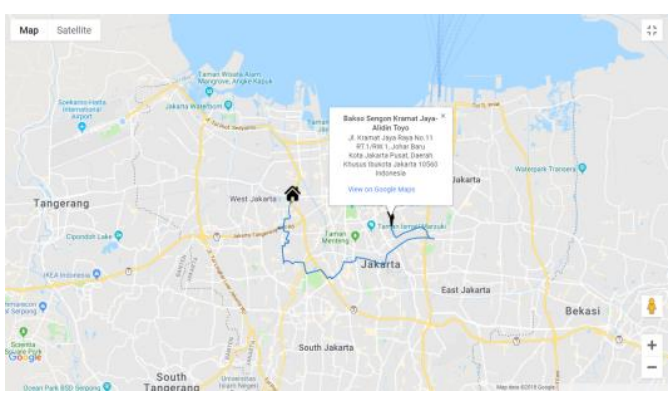

Gambar 10. Rute terpendek dari Alidin Toyo menuju UNTAR

Menunjukan rute terpendek yang dapat dilalui dari Bakso Sengon Kramat Jaya-Alidin Toyo UNTAR.

5. The Way Bookstore \& Café menuju BINUS

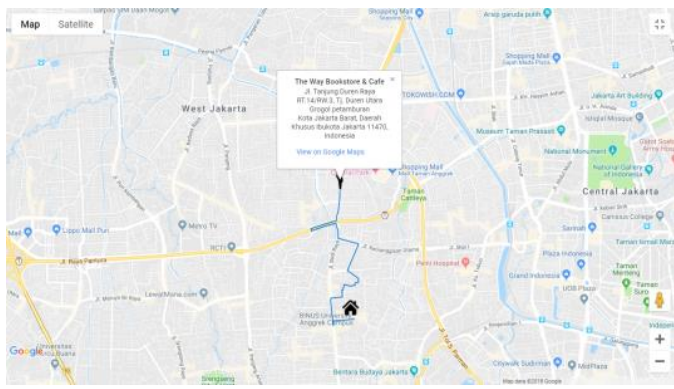

Gambar 11. Rute terpendek dari The Way Bookstore \& Café menuju BINUS

Menunjukan rute terpendek yang dapat dilalui dari The Way Bookstore \& Café menuju BINUS.

Berikut adalah tabel hasil pengujian sistem yang sudah penulis buat berdasarkan data asli dari map:

Tabel 1 Tabel hasil pengujian

\begin{tabular}{|l|l|l|l|}
\hline $\begin{array}{l}\text { N } \\
\text { o }\end{array}$ & Titik awal & $\begin{array}{l}\text { Kampus } \\
\text { IT } \\
\text { tujuan }\end{array}$ & Hasil \\
\hline 1 & $\begin{array}{l}\text { Bank Sinar } \\
\text { MAS, Petojo }\end{array}$ & UBM & $\begin{array}{l}\text { Rute } \\
\text { terpendek }\end{array}$ \\
\hline 2 & $\begin{array}{l}\text { Bubur Ayam } \\
\text { Pinangsia }\end{array}$ & UBM & $\begin{array}{l}\text { Rute } \\
\text { terpendek }\end{array}$ \\
\hline 3 & $\begin{array}{l}\text { RX Game } \\
\text { Jl. Lodan } \\
\text { Raya UBM }\end{array}$ & $\begin{array}{l}\text { Rute } \\
\text { terpendek }\end{array}$ \\
\hline 4 & $\begin{array}{l}\text { RM Karya } \\
\text { Minang JI. } \\
\text { Lodan Raya }\end{array}$ & UBM & $\begin{array}{l}\text { Rute } \\
\text { terpendek }\end{array}$ \\
\hline
\end{tabular}




\begin{tabular}{|c|c|c|c|}
\hline 5 & $\begin{array}{l}\text { PT Nipsea } \\
\text { Paint And } \\
\text { Chemicals } \\
\text { Co Ltd }\end{array}$ & $\begin{array}{l}\text { UBM } \\
\text { Mulia }\end{array}$ & $\begin{array}{l}\text { Rute } \\
\text { terpendek }\end{array}$ \\
\hline 6 & $\begin{array}{l}\text { Seafood } \\
212 \\
\text { BINTANG } \\
\text { LAUT } \\
\text { ANCOL }\end{array}$ & UBM & $\begin{array}{l}\text { Rute } \\
\text { terpendek }\end{array}$ \\
\hline 7 & $\begin{array}{lr}\text { Zul Ladies } \\
\text { Fashion Jl. } \\
\text { Kp. Rw. } \\
\text { Sawah }\end{array}$ & $\begin{array}{l}\text { Atmajay } \\
\text { a }\end{array}$ & $\begin{array}{l}\text { Rute } \\
\text { terpendek }\end{array}$ \\
\hline 8 & $\begin{array}{lr}\text { Gado2 } & \& \\
\text { Nasi Soto } & \text { Syam Karet } \\
\text { A }\end{array}$ & $\begin{array}{l}\text { Atmajay } \\
\text { a }\end{array}$ & $\begin{array}{l}\text { Rute } \\
\text { terpendek } \\
\text { terpendek }\end{array}$ \\
\hline 9 & $\begin{array}{l}\text { Warung } \\
\text { Sate } \\
\text { Madura, } \\
\text { Kebayoran }\end{array}$ & $\begin{array}{l}\text { Atmajay } \\
\text { a }\end{array}$ & $\begin{array}{l}\text { Rute } \\
\text { terpendek }\end{array}$ \\
\hline 10 & $\begin{array}{l}\text { An Hotel } \\
\text { Jakarta, } \\
\text { Kuningan }\end{array}$ & $\begin{array}{l}\text { Atmajay } \\
\text { a }\end{array}$ & $\begin{array}{l}\text { Rute } \\
\text { terpendek }\end{array}$ \\
\hline 11 & $\begin{array}{l}\text { Maharani } \\
\text { Collection, } \\
\text { Jatinegara }\end{array}$ & UNJ & $\begin{array}{l}\text { Rute } \\
\text { terpendek }\end{array}$ \\
\hline 12 & $\begin{array}{c}\text { Apotek } \\
\text { Parantha } \\
\text { Farma Jl. } \\
\text { Cipinang } \\
\text { Baru }\end{array}$ & UNJ & $\begin{array}{l}\text { Rute } \\
\text { terpendek }\end{array}$ \\
\hline 13 & $\begin{array}{l}\text { STMA } \\
\text { Trisakti }\end{array}$ & UNJ & $\begin{array}{l}\text { Rute } \\
\text { terpendek }\end{array}$ \\
\hline 14 & $\begin{array}{l}\text { Sinar Garut } \\
\text { Mekarsari } 2\end{array}$ & UNJ & $\begin{array}{l}\text { Rute } \\
\text { terpendek }\end{array}$ \\
\hline 15 & $\begin{array}{l}\text { Mendoan } \\
\text { Cempaka } \\
\text { Warna }\end{array}$ & UNJ & $\begin{array}{l}\text { Rute } \\
\text { terpendek }\end{array}$ \\
\hline 16 & $\begin{array}{l}\text { Bakso } \\
\text { Sengon } \\
\text { Kramat } \\
\text { Jaya-Alidin } \\
\text { Toyo }\end{array}$ & UNTAR & $\begin{array}{l}\text { Rute } \\
\text { terpendek }\end{array}$ \\
\hline 17 & $\begin{array}{ll}\text { Evo } & \text { Distro } \\
\text { Jl. } & \text { Gajah } \\
\text { Mada } & \end{array}$ & UNTAR & $\begin{array}{l}\text { Rute } \\
\text { terpendek }\end{array}$ \\
\hline 18 & $\begin{array}{l}\text { Masjid Al- } \\
\text { Huda grogol }\end{array}$ & UNTAR & $\begin{array}{l}\text { Rute } \\
\text { terpendek }\end{array}$ \\
\hline 19 & $\begin{array}{l}\text { Youth } \\
\text { Center GRII } \\
\text { Daan Mogot }\end{array}$ & UNTAR & $\begin{array}{l}\text { Rute } \\
\text { terpendek }\end{array}$ \\
\hline 20 & $\begin{array}{l}\text { Kost Tropis } \\
\text { Wanita Jl. } \\
\text { Tanjung } \\
\text { Duren }\end{array}$ & UNTAR & $\begin{array}{l}\text { Rute } \\
\text { terpendek }\end{array}$ \\
\hline 21 & $\begin{array}{l}\text { The Way } \\
\text { Bookstore \& }\end{array}$ & BINUS & $\begin{array}{l}\text { Rute } \\
\text { terpendek }\end{array}$ \\
\hline
\end{tabular}

\begin{tabular}{|l|l|l|l|}
\hline & Cafe & & \\
\hline 22 & $\begin{array}{l}\text { MIE AYAM } \\
\text { BABE } \\
\text { AHDA, Duri }\end{array}$ & BINUS & $\begin{array}{l}\text { Rute } \\
\text { terpendek }\end{array}$ \\
\hline 23 & $\begin{array}{l}\text { PT. SINAR } \\
\text { PALASARI } \\
\text { INDONESIA }\end{array}$ & BINUS & $\begin{array}{l}\text { Rute } \\
\text { terpendek }\end{array}$ \\
\hline 24 & $\begin{array}{l}\text { Taman } \\
\text { Komplek } \\
\text { DPR }\end{array}$ & BINUS & $\begin{array}{l}\text { Rute } \\
\text { terpendek }\end{array}$ \\
\hline 25 & $\begin{array}{l}\text { Bakso } \\
\text { Rusuk Total } \\
\text { Solo } \\
\text { Kemanggisa } \\
n\end{array}$ & BINUS & $\begin{array}{l}\text { Rute } \\
\text { terpendek }\end{array}$ \\
\hline 26 & $\begin{array}{l}\text { Pisang ljo Si } \\
\text { Nona }\end{array}$ & Esa & $\begin{array}{l}\text { Rute } \\
\text { terpendek }\end{array}$ \\
\hline 27 & $\begin{array}{l}\text { WARTUR } \\
\text { Intercone }\end{array}$ & $\begin{array}{l}\text { Mercu } \\
\text { Buana }\end{array}$ & $\begin{array}{l}\text { Menunjuka } \\
\text { rute } \\
\text { terpendek }\end{array}$ \\
\hline
\end{tabular}

Setelah melakukan pengujian penulis dapat menyimpulkan bahwa tingkat ketepatan rute yang didapatkan dari aplikasi ini adalah sebesar $75 \%$, dikarenakan masih ada beberapa posisi dan rute yang tidak $100 \%$ akurat.

\section{Kesimpulan}

Berdasarkan permasalahan yang telah dijabarkan dan serangkaian penelitian yang telah penulis lakukan. Maka dapat disimpulkan beberapa hal sebagai berikut :

1. Cara menemukan rute tercepat dan rute terpendek dari suatu lokasi ke lokasi yang lain, dalam hal ini berupa suatu persimpangan ke persimpangan yang lain adalah dengan mengunakan algoritma Djikstra dengan input berupa persimpangan asal dan tujuan serta sebuah graf yang merepresentasikan node sebagai persimpangan dan simpul atau path sebagai jalur yang menghubungkannya.

2. Faktor-faktor yang dapat diperhitungkan dalam mencari jalur tercepat yaitu waktu tempuh dari suatu persimpangan ke persimpangan lainnya.

\section{Referensi}

Munir, Rinaldi. (2005), Buku Teks IImu Komputer Matematika Diskrit Edisi Ketiga, Informatika, Bandung, ISBN/ISSN : 979-96-446-3-1.

Munir, Rinaldi. (2005), Algoritma dan Pemrograman dalam Bahasa Pascal dan C Buku 1, Informatika, Bandung, ISBN : 979-95779-2-6. 
Peranginangin, Kasiman. 2006. Aplikasi Web dengan PHP dan MySQL. Andi. Yogyakarta. ISBN: 979-763-526-0.

Kristanto, Andri. (2003), Struktur Data dengan $\mathrm{C}_{++}$, Graha IImu, Yogyakarta, ISBN: 978-979-756-4506. 1.

Chamero, Juan. 2006. Djkstra's Algorithm As a Dynamic Programming strategy, http://www.intag.org/downloads/ds_0 06.pdf, Diakses 10 Oktober 2018.

Sjukani, Moh. (2007), Algoritma (Algoritma dan Struktur Data 1) dengan C, C++, dan Java, Mitra Wacana Media, Jakarta, ISBN/ISSN : 978-979-109229-6.

Syahputra, Siswan. 2017, Penentuan Rute Terpendek Pendistribusian Naskah Ujian Nasional Menggunakan Algoritma Dijkstra, Jurnal Teknik Informatika Kaputama (JTIK), Vol 1 No.1, Januari 2017, ISSN :25489704.

Udariansyah, Devi. 2018, Menggunakan Protokol Routing OSPF (Open Source Path First) Menggunakan GNS3 Untuk Mencari Jalur Terpendek Dengan Menerapkan Algoritma Dijkstra, Jurnal Informanika, Volume 4 No.1, ISSN :2407-1730.

Kirill Golubev, Aleksander Zagarskikh, dan Andrey Karsakov. 2016. Dijkstrabased Terrain Generation Using Advanced Weight Functions, Procedia Computer Science 101, 2016, Pages 151 - 159, doi: 10.1016/j.procs.2016.11.019.

Yi-zhou Chen, Shi-fei Shen, Tao Chen, dan Rui Yang. 2014. Path Optimization Study for Vehicles Evacuation Based on Dijkstra algorithm, Procedia Engineering 71 (2014) 159 - 165, doi: 10.1016/j.proeng.2014.04.023.

Pramod Pandey dan Sunanda Dixit. 2014. Railway Route Optimization System Using Dijkstra Method, International Journal on Recent and Innovation Trends in Computing and Communication, ISSN: 2321-8169.
Bartosz Musznicki, Mikołaj Tomczak, dan Piotr Zwierzykowski. 2013. Geografic Dijkstra-Based Multicast Algorithm For Wireless Sensor Networks, Image Processing \& Communication, vol. 17, no. 1-2, pp. 33-46, doi : 10.2478/v10248-012-0013-3.

Fitria, Apri Triansyah. 2013. Implementasi Algoritma Dijkstra Dalam Aplikasi Untuk Menentukan Lintasan Terpendek Jalan Darat Antar Kota Di Sumatera Bagian Selatan, Jurnal Sistem Informasi (JSI), VOL. 5, NO. 2, Oktober 2013, Halaman 611-621, ISSN Online : 2355-4614.

Muhammad Syamsuddin Yusuf, Hanifah Muslimah Az-Zahra, Diah Harnoni Apriyanti. 2017. Implementasi Algoritma Dijkstra Dalam Menemukan Jarak Terdekat Dari Lokasi Pengguna Ke Tanaman Yang Di Tuju Berbasis Android (Studi Kasus di Kebun Raya Purwodadi, Jurnal Pengembangan Teknologi Informasi dan IImu Komputer, Vol. 1, No. 12, Desember 2017, hlm. 17791787, e-ISSN: 2548-964X

Edmonds, Jeff. 2008, How to Think About Algorithm, Cambridge University Press, New York. ISBN-13: 9780521614108

Ojekudo, Nathaniel Akpofure dan Akpan, Nsikan Paul. 2017. Anapplication of Dijkstra's Algorithm to shortest route problem, Volume 13, Issue 3 Ver. 1 (May. - June. 2017), PP 20-32, eISSN: 2278-5728.

Windi Eka Yulia R., Dwiretno Istiadi, Abdul Roqib. 2015. Pencarian Spbu Terdekat Dan Penentuan Jarak Terpendek Menggunakan Algoritma Dijkstra (Studi Kasus Di Kabupaten Jember), Vol: 4, No. 1, Maret 2015, ISSN: 2302. 